\title{
Humpback whales Megaptera novaeangliae in the Arabian Sea
}

\author{
Yuri A. Mikhalev* \\ South Ukranian Pedagogical University, Staroportofrankovskaya 26, Odessa 270020, Ukraine
}

\begin{abstract}
The population identity of humpback whales Megaptera novaeangliae in the Arabian Sea has long been a matter of dispute. New information is presented from this region, based upon whaling and observations conducted by the Sovet Union, primarily in November 1966. In that month, a total of 238 humpbacks were killed of the coasts of Oman, Pakistan and northwestern India; 4 others were killed in 1965. Biological examination of these whales showed that they differed significantly from Antarctic humpbacks in terms of size, coloration, body scars and pathology. In addition, analysis of the length distribution of 38 foetuses indicates that the reproductive cycle of the Arabian Sea whales was unequivocally that of a northern hemisphere population. Mean lengths were $12.8 \mathrm{~m}$ for males (range: 9.5 to $14.9 \mathrm{~m}, \mathrm{n}=126$ ) and $13.3 \mathrm{~m}$ for females (range: 9.5 to $15.2 \mathrm{~m}, \mathrm{n}=112$ ). All whales $12.5 \mathrm{~m}$ or more in length were sexually mature. Among 97 females examined, $12(12.4 \%)$ were immature. Of the 85 mature females, $39(45.9 \%)$ were pregnant, $3(3.5 \%)$ were lactating, and $43(50.6 \%)$ were resting. A more plausible pregnancy rate, adjusted for underrepresentation of lactating females, was estimated at $39 \%$. A majority of stomachs examined contained food, including euphausiids and fish. Overall, the data presented here argue strongly that Arabian Sea humpbacks constitute a discrete population which remains in tropical waters year-round, a situation which is unique for this species.
\end{abstract}

KEY WORDS: Humpback whale A Arabian Sea - Indian Ocean - Population biology $\cdot$ Reproduction

\section{INTRODUCTION}

The humpback whales Megaptera novaeangliae of the Arabian Sea have long represented an enigma to cetologists. Elsewhere, humpbacks undertake welldocumented seasonal migrations from summer feeding areas in high latitudes to winter mating and calving grounds in tropical waters, where they typically fast (Chittleborough 1965, Dawbin 1966, Katona \& Beard 1990, Perry et al. 1990). However, the northern Indian Ocean has no polar component; thus, the humpbacks that are found there must either remain within tropical waters year-round or migrate great distances to feeding grounds in other oceans.

Little is known of this population, in large part because of the lack of observer effort in this region and

\footnotetext{
- Address for correspondence: c/o R. L. Brownell Jr, NMFS, Southwest Fisheries Science Center, PO Box 271, La Jolla, California 92038, LSA. E-mail: brownell@caliban.ucsd.edu
}

the scattered nature of historical sighting reports. Van Beneden (1887) mentioned humpbacks off the coasts of Oman and Pakistan, and Gervais (1888) described a humpback (Megaptera indica) from Basra Bay in the Persian Gulf. The maps compiled by Townsend (1935) from catch logs of 19 th century whalers show no humpbacks north of Madagascar, despite the fact that there were whaling operations off the coast of the Arabian Peninsula, where sperm whales were taken (Wray \& Martin 1983). Tomilin (1967, p 303) concluded, probably based upon these sources, that 'a small (seemingly insignificant) number of humpbacks passing north of Madagascar reach the coast of Arabia and Baluchistan, and even enter the Persian Gulf'.

Slijper et al. (1964) reported humpbacks at the entrance to the Gulf of Aden, near Oman, in the Persian Gulf and off Ceylon (present-day Sri Lanka). Yukhov (1969) summarized reports from survey vessels and noted sightings of small groups of humpbacks east of Cape Fartak, Oman, in October and November 
of 1964-65. The northern part of the Indian Ocean is included on a map of humpback whale habitat presented by Borisov in Yablokov et al. (1972, Fig. 189, p 329), but no source is given for this information. Other sightings and strandings of humpback whales in the northern Indian Ocean are summarized by Reeves et al. (1991) and Papastavrou \& Salm (1991).

Explanations of the origin and seasonal movements of humpbacks in this region have been varied. Tomilin (1967) and Brown (1957) expressed a common view that Arabian Sea humpbacks migrated from Antarctic feeding grounds, while Slijper et al. (1964) speculated that they came from the North Pacific. Whitehead (1985) recorded humpback whale songs off Oman in January, and determined that the structure of these songs was different from those recorded in the North Pacific and North Atlantic; he therefore hypothesized that the population was isolated and that it remained in local waters year-round. Reeves et al. (1991) summarized data from the northern Indian Ocean and noted that the species appeared to be present in the Arabian Sea region throughout the year. While agreeing with Whitehead that this supported the idea of a resident population, they cautioned that none of the proposed hypotheses could be ruled out: existing data were too sparse, and there was virtually no biological information on the animals of this region.

It was recently reported that the Soviet Union conducted large-scale illegal whaling operations, including for protected species (see Yablokov 1994, Zemsky et al. 1995). Although the majority of this activity occurred in the Antarctic, extensive illegal catches were also made in the northern hemisphere. Here, I present formerly secret data from catches of humpback whales taken in the Arabian Sea, primarily in the autumn of 1966 . Analysis of these data provides strong evidence for the existence of a discrete population of this species that both feeds and breeds in the tropical waters of the northwestern Indian Ocean.

\section{DATA AND OBSERVATIONS}

With the exception of 4 animals killed in 1965, the data summarized here come from catches of humpback whales made in November of 1966. These catches were never reported to the Bureau of International Whaling Statistics in Norway or to the International Whaling Commission; they are included in the overall totals appearing in the new catch report on Soviet whaling operations provided by Zemsky et al (1995).

Prior to consideration of the results, it will be useful to provide a brief narrative of the development of Soviet whaling in the Arabian Sea. In the autumn of
1963, the Soviet floating factory 'Slava' and her associated catcher vessels steamed through the Red Sea for the first time en route to the whaling grounds of the Antarctic. During this voyage, a scout vessel noted 20 to 30 humpback whales in the Gulf of Aden. The first humpback whale was killed off the northeastern coast of Madagascar at $21^{\circ} 48^{\prime} \mathrm{S}, 50^{\circ} 42^{\prime} \mathrm{E}$. During the following whaling season (that of 1964-65), the factory ships 'Slava' and 'Sovetskaya Ukraina' travelled together through the Suez Canal. Whaling subsequently began in the Gulf of Aden, and then moved across the tropical zone to the southern tip of India and Ceylon. No humpback whales were observed, probably because (as is related later) at that time of year they appear to occupy more northerly regions of the Arabian Sea.

On the 1965-66 season voyage, the fleets again began whaling in the Gulf of Aden. In addition to other species, 'Slava' killed a $13.8 \mathrm{~m}$ male humpback on 12 November $\left(14^{\circ} 21^{\prime} \mathrm{N}, 52^{\circ} 34^{\prime} \mathrm{E}\right)$, as well as a $14.1 \mathrm{~m}$ male and an animal of unrecorded length and sex on 18 November ( $15^{\circ} 53^{\prime} \mathrm{N}, 52^{\circ} 22^{\prime} \mathrm{E}$ ). 'Sovetskaya Ukraina' also took 1 humpback (details not recorded). After whaling in the Gulf of Aden, 'Slava' steamed south to the region of the Seychelles, while 'Sovetskaya Ukraina' proceeded towards Ceylon as on previous voyages, only later turning south. No other humpback whales were observed until the vessels reached Antarctic waters

During the 1966-67 season. 'Slava' did not operate, but 'Sovetskaya Ukraina' began whaling in the Gulf of Aden after transiting the Suez Canal. It appears that the fleet commanders took into consideration the previous catches of humpbacks in more northerly areas, as well as a message from the shrimp trawler 'Van Gogh', commanded by a well-known former whaling captain named Solyanik. Solyanik reported seeing 2 aggregations of humpback whales off the coast of Pakistan in March (at $25^{\circ} 04^{\prime} \mathrm{N}, 65^{\circ} 21^{\prime} \mathrm{E}$, and $24^{\circ} 56^{\prime} \mathrm{N}, 61^{\circ} 41^{\prime} \mathrm{E}$ ). In addition, the rumor that Kuwait was proposing to begin whaling in the Persian Gulf area reinforced the fleet commanders' belief that the northerly region must represent an important habitat for whales. Thus, in early November 1966, 'Sovetskaya Ukraina' proceeded north along the coast of Oman and across the Arabian Sea to the coasts of Pakistan and northwestern India.

\section{RESULTS}

Total catch, sex ratio and length of whales

During a $10 \mathrm{~d}$ period between 5 and 15 November 1966, the 'Sovetskaya Ukraina' fleet killed a total of 
238 humpback whales. Of these, 62 were taken in $3 \mathrm{~d}$ (5-7 November) off Oman, in 2 regions: 30 in the vicinity of the Kuria Maria Islands, and 32 off the island of Masirah. Of the others, 164 were killed in the Gulf of Kutch off Pakistan on 8-14 November, while 12 others were taken on 15 November off India, west of Bombay. These catches are plotted in Fig 1 A scout vessel recorded sightings of an additional 34 humpbacks; of these, 20 were in the approximate position $18^{\circ} \mathrm{N}, 57^{\circ} \mathrm{E}$ (northeast of the Kuria Maria Islands), and the remainder in various locations off the coast of Pakistan.

Of the 238 humpbacks killed, 126 $(52.9 \%)$ were male and $112(47.1 \%)$ female, a sex ratio which does not deviate significantly from parity $\left(\chi^{2}=\right.$ 0.412, $\alpha=0.05$, $\mathrm{df}=1$ ) The lengths of

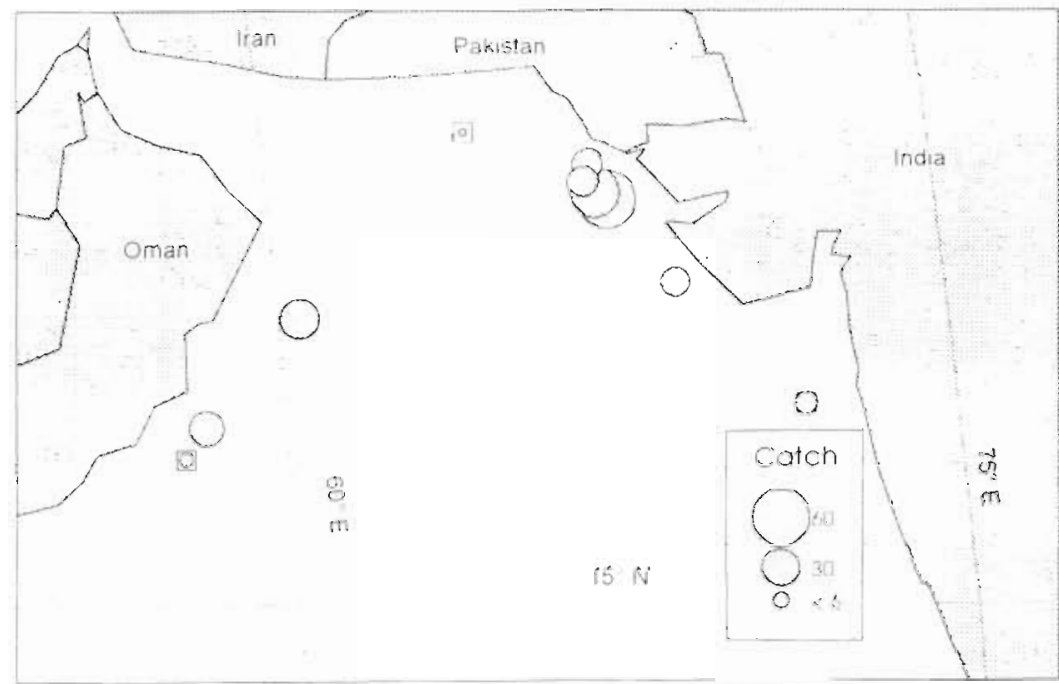

Fig. 1. Soviet catches of humpback whales Megaptera novaeangliae in the Arabian Sea, November 1966. Symbols in boxes indicate catches of 2 (Pakistan) and 5 (Oman) whales these animals are presented by sex in Fig. 2. Among males, lengths ranged from 9.5 to $14.9 \mathrm{~m}$ (mean $=12.8$ $\mathrm{m}, \mathrm{SE}=0.937$ ). Females ranged in size from 9.5 to 15.2 $m$ (mean $=13.3 \mathrm{~m}, \mathrm{SE}=1.270)$. The overall mean length for both sexes was $13.1 \mathrm{~m}$.

\section{Reproductive biology of females}

A total of 97 female humpbacks were examined to determine their reproductive condition; the resulting data are given by length in Table 1. All females of $11.5 \mathrm{~m}$ or more in length were found to be sexually mature, as determined from the presence of corpora bodies or from the condition of the endometrium (see Chittleborough 1958). Twelve $(12.4 \%)$ of the 97 females were immature, having no evidence of past or present ovulation. Of the 85 mature females, 39 $(45.9 \%)$ were pregnant, $3(3.5 \%)$ were lactating, and $43(50.6 \%)$ were resting (neither pregnant nor lactating)

The apparent pregnancy rate of $45.9 \%$ is misleading, since lactating (and therefore mature) females are underrepresented in the catch. A more accurate rate can be calculated using a method employed by Chittleborough (1965), who made the reasonable assumption that a humpback whale population will contain an approximately equal number of pregnant and lactating fe-

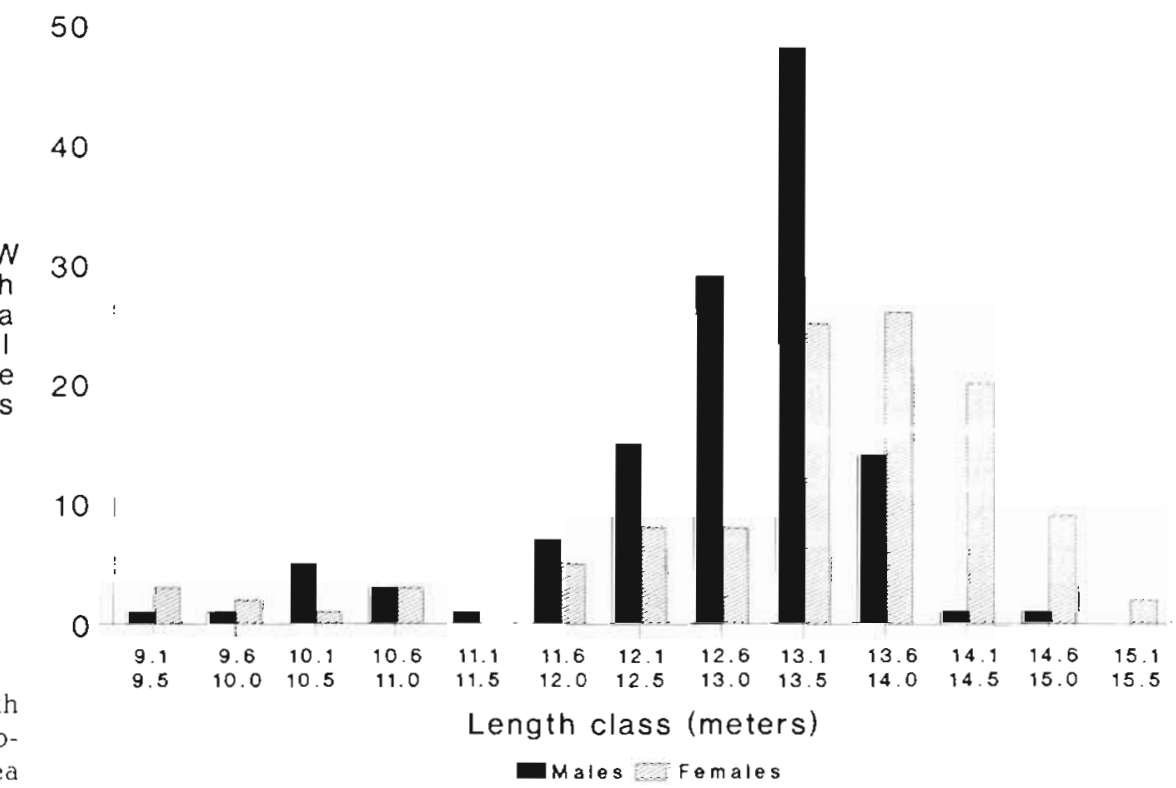

Fig. 2. Megaptera novaeangliae. Length frequencies of male and female humpback whales killed in the Arabian Sea 
Table 1. Megaptera novaeangliae. Reproductive condition of female humpback whales caught in the Arabian Sea

\begin{tabular}{|c|c|c|c|c|c|c|c|c|c|}
\hline \multirow[t]{2}{*}{ Length $(\mathrm{m})$} & \multirow[t]{2}{*}{ Total } & \multicolumn{2}{|c|}{ Pregnant } & \multicolumn{2}{|c|}{ Lactating } & \multicolumn{2}{|c|}{ Resting } & \multicolumn{2}{|c|}{ Immature } \\
\hline & & $\mathrm{n}$ & $\%$ & $\mathrm{n}$ & $\%$ & $\mathrm{n}$ & $\%$ & $\mathrm{n}$ & $\%$ \\
\hline $9.1-11.5$ & 9 & & & & & & & 9 & 100.0 \\
\hline $11.6-12.0$ & 4 & & & 1 & 25.0 & 1 & 25.0 & 2 & 50.0 \\
\hline $12.1-12.5$ & 7 & & & 1 & 4.3 & 5 & 71.4 & 1 & 14.3 \\
\hline $12.6-13.0$ & 8 & 2 & 25.0 & 1 & 12.5 & 5 & 62.5 & & \\
\hline $13.1-13.5$ & 23 & 15 & 65.2 & 1 & 4.4 & 7 & 30.4 & & \\
\hline $13.6-14.0$ & 20 & 7 & 35.0 & & & 13 & 65.0 & & \\
\hline $14.1-14.5$ & 15 & 9 & 60.0 & 1 & 6.7 & 5 & 33.3 & & \\
\hline $14.6-15.0$ & 9 & 2 & 22.2 & & & 7 & 77.8 & & \\
\hline $15.1-15.5$ & 2 & 2 & 100.0 & & & & & & \\
\hline Total & 97 & 39 & 40.1 & 3 & 3.1 & 43 & 44.4 & 12 & 12.4 \\
\hline
\end{tabular}

mate is very likely to be too low. If we substitute a figure of $10 \%$, then the adjusted pregnancy rate for the Arabian Sea humpbacks becomes 0.39 (39\% of all mature females, which would comprise 43 pregnant, 35 lactating and not pregnant, and 43 resting).

The low percentage of lactating females in the catch was not an artifact of sampling, which was largely indiscriminate: the scarcity of mother/ calf pairs was confirmed by a scout vessel, which recorded only one other such pair in the region.

Foetuses were examined from 37 of the 39 pregnant females. One $14.6 \mathrm{~m}$

Table 2. Megaptera novaeangliae. Lengths of female and male foetuses, and of the mature females carrying them. The mean foetal length is $232 \mathrm{~cm}$ ( $\mathrm{SE}=37.63, \mathrm{n}=38$ ). Note the one case of twins

\begin{tabular}{|c|c|c|c|}
\hline \multicolumn{2}{|c|}{ Female foetuses } & \multicolumn{2}{|c|}{ Male foetuses } \\
\hline $\begin{array}{l}\text { Length of } \\
\text { mother }(\mathrm{m})\end{array}$ & $\begin{array}{l}\text { Length of } \\
\text { foetus }(\mathrm{cm})\end{array}$ & $\begin{array}{l}\text { Length of } \\
\text { mother }(m)\end{array}$ & $\begin{array}{l}\text { Length of } \\
\text { foetus }(\mathrm{cm})\end{array}$ \\
\hline 13.0 & 140 & 13.2 & 64 \\
\hline 14.1 & 142 & 12.8 & 140 \\
\hline 14.5 & 160 & 14.3 & 161 \\
\hline 11.9 & 170 & 14.2 & 164 \\
\hline 13.7 & 180 & 14.0 & 170 \\
\hline 14.2 & 182 & 13.2 & 198 \\
\hline 13.1 & 183 & 13.1 & 200 \\
\hline 14.6 & 190,210 & 12.1 & 213 \\
\hline 13.2 & 200 & 13.8 & 230 \\
\hline 13.7 & 230 & 13.3 & 275 \\
\hline 13.4 & 250 & 14.3 & 340 \\
\hline 13.1 & 250 & 14.3 & 375 \\
\hline 14.3 & 260 & & \\
\hline 13.7 & 260 & & \\
\hline 13.3 & 269 & & \\
\hline 13.3 & 270 & & \\
\hline 12.7 & 280 & & \\
\hline 14.4 & 280 & & \\
\hline 13.4 & 280 & & \\
\hline 13.1 & 295 & & \\
\hline 15.2 & 300 & & \\
\hline 13.6 & 310 & & \\
\hline 13.3 & 310 & & \\
\hline 15.2 & 330 & & \\
\hline 13.3 & 353 & & \\
\hline
\end{tabular}

males. In the current case, figures of 39 pregnant, 39 lactating and 43 resting females would be used. However, one must also account for the fact that a minority of the lactating females will be pregnant. Chittleborough (1965), who did not attempt to compensate for this, gave an estimate of $8.5 \%$ for simultaneously pregnant and nursing animals. Since the data from which this figure was drawn are known to be biased, this estifemale was carrying twin female foetuses, which were 190 and $210 \mathrm{~cm}$ in length. Lengths of the pregnant females and of their respective foetuses are summarized in Table 2 . Female foetuses $(26$, or $68.4 \%$ of the 38 examined, including the twins) predominate in the sample, but the overall sex ratio is not significantly different from parity $\left(\chi^{2}=2.602, \alpha=0.05, \mathrm{df}=1\right)$. Overall, the range of sizes among all the foetuses is relatively small: if one disregards the single $64 \mathrm{~cm}$ embryo, all the foetal leng ths lie between 140 and $375 \mathrm{~cm}$, with a mean of $232 \mathrm{~cm}(\mathrm{SE}=37.63)$.

\section{Stomach contents}

The stomachs of 190 animals were examined. Of these, 19 (10.0\%) had full stomachs. Among the remaining stomachs, $77(40.5 \%)$ were approximately half full, 65 (34.2\%) contained a small amount of food, and $29(15.3 \%)$ were empty. In the majority of cases, stomach contents consisted of small ( 1 to $2 \mathrm{~cm}$ length) euphausiids of undetermined species. However, remains of fish were also found, including Scomber spp. and Sardinella spp. (in one animal, nearly a ton of sardines was discovered). During the period 5-7 November, off the coast of Oman, feeding on only fish was observed. Some mixed feeding on euphausiids and fish was noted in the northeastern Arabian Sea.

\section{Pathology}

Many humpback whales in the Arabian Sea were found to have hepatic changes. Of 38 animals examined, pathology of the liver was reported in $26(68.5 \%)$ cases. Degeneration of adjoining tissue in peripheral sections of the liver was also observed. Cone-shaped growths, sometimes up to $20 \mathrm{~cm}$ in diameter, were apparent, and bile ducts were blocked by a dense, 
dirty gray paste. The observed pathology was similar to that caused by infection with trematode parasites, but none were found in the affected areas. Atherosclerosis of liver blood vessels was also noted in some cases, as well as hardening and thickening of arterial walls in the rectal area.

\section{External appearance}

The external surface of the skin of the Arabian Sea humpbacks had relatively few barnacles, and those examined were quite small. Their species was not determined, although all belonged to the genus Coronula (the most common barnacle type found on humpback whalesi. Because white oval scars are commonly found on the skin of Antarctic humpback whales (Matthews 1937; author's unpubl data), 30 of the Arabian Sea whales were examined specifically for this feature. No such scars were found.

The body coloration of 65 humpbacks was recorded for comparison to that of other populations. A subjective classification was used, in which ventral coloration was divided into 3 categories similar to those employed by Matthews (1937) and Omura (1953). These are predominantly black (type I), mixed/marbled (type II), and predominantly white (type III). Ventral coloration of whales in the second category is not dominated by either black or white, and these animals have white patches of varying size in the throat and genital regions. Of the 65 whales examined, $30(46.2 \%)$ were of type I, 17 (26.2\%) of type II, and 18 (27.6\%) of type III.

\section{DISCUSSION}

\section{Population identity}

The data presented here argue strongly that the humpback whales found in the Arabian Sea constitute a discrete population that remains in the region yearround, both feeding and breeding in tropical waters. Evidence for this can be found in all aspects of the Soviet data, including the temporal occurrence of the whales, as well as their reproductive cycle, length. appearance and parasitology. These topics are discussed separately below.

\section{Occurrence}

The occurrence of humpback whales off Pakistan in March, as reported by the shrimp trawler 'Van Gogh', is not necessarily inconsistent with the belief of Brown
(1957) and Tomilin (1967) that these whales originate in the southern hemisphere. However, this is not the case with the Soviet catches reported here, which were of feeding humpback whales in the month of November. Numerous sources, including Townsend (1935), Chittleborough (1953, 1965) and Dawbin (1966), clearly indicate that by the month of November or December all southern hemisphere populations of humpback whales are to be found on their austral summer feeding grounds south of latitude $35-40^{\circ} \mathrm{S}$. Extensive distributional information derived from illegal Soviet catches of thousands of southern hemipshere humpback whales reinforces this (author's unpubl data). Furthermore, neither scientific research vessels nor whaling vessels in the 'Slava' and 'Sovetskaya Ukraina' fleets, sighted any humpbacks between $10^{\circ} \mathrm{N}$ and $20^{\circ} \mathrm{S}$ on their passages to and from the Antarctic during the months of October to December or April to May. It is also noteworthy that observers on scout and catcher boats off the coasts of Oman, Pakistan and India in November and early December reported seeing a general northerly or northeasterly movement of humpbacks in this region.

In short, the occurrence of feeding humpbacks in the Arabian Sea at a time of year when southern hemisphere populations are thousands of miles to the south, and the absence of sightings in intermediate areas, strongly supports the hypothesis that these animals are not part of the same population. Slijper et al.'s (1964) suggestion that Arabian Sea humpbacks come from the North Pacific was largely speculative, and there is little reason to suppose that animals from the latter population would undertake such a large longitudinal migration. That humpback whale songs from Oman are different from those of the North Pacific (Whitehead 1985) is significant in this regard, since differences in song structure appear to be a reliable indicator of population segregation (Payne \& Guinee 1983)

\section{Reproduction}

The data on the reproductive cycle of the Arabian Sea animals provide the most compelling evidence for their separation from austral populations of humpback whales. Although uncertainties exist regarding the precise rate and pattern of foetal growth in this species, even a broad range of estimated conception dates for the foetuses examined shows that the reproductive cycle is unequivocally that of a humpback population from the northern, not southern, hemisphere. If one assumes that the pattern of prenatal growth in the humpback whale is monoparabolic (Ohsumi et al 1958, Laws 1959, Mikhalev 1980), the foetal length data reported here imply a 3 to 4 mo mating season 
lasting from early January to late May, with a peak in early March. With a gestation period of 1.1 or $11 \frac{1}{2}$ mo (Chittleborough 1958), calving should begin in December, with a peak in February. This is entirely consistent with the data: the largest foetuses in the November catch were already 340 to $375 \mathrm{~cm}$ in length, close to the approximate average length at birth of $427 \mathrm{~cm}$ or 14 feet (Chittleborough 1958, Nishiwaki 1959). The single exception, a foetus of $64 \mathrm{~cm}$, is certainly of interest; given that a foetus of such length would be approximately 4 mo of age, and thus conceived in July, this could be interpreted as a southern hemisphere whale. However, aseasonal conceptions in other humpback populations, while rare, are not unknown (Matthews 1937, Chittleborough 19.58).

Overall, the relatively narrow range of foetal lengths recorded indicates a population with a single welldefined breeding season during the boreal winter. This conclusion is further supported by recordings of humpback whale songs in the Arabian Sea in January (Whitehead 1985); songs are sung solely by males, and are probably primarily a breeding display (see review in Clapham 1996). The timing of this season, from December to April/May, is synchronous with the mating and calving of other northern hemisphere populations, specifically those in the North Atlantic (Whitehead \& Moore 1982, Katona \& Beard 1990) and North Pacific (Nishiwaki 1966, Tomilin 1967, Perry et al. 1990).

The adjusted pregnancy rate given here $(0.39)$ is within the range of reproductive rates reported from other whaling data and from long-term studies of identified individual humpbacks. Among whaling studies, these include 0.37 (western Australia, Chittleborough 1965), 0.39 (Aleutian Islands; value calculated by Chittleborough 1965 from data in Nishiwaki 1959), and 0.46 (California, Clapham et al. 1997; although if adjusted for lactating females in the manner described earlier, this rate would be 0.40 ). From long-term studies of living whales, calculated reproductive rates have commonly been expressed as 'calves per mature female per year'. Examples include 0.37 (southeastern Alaska, Baker et al. 1987), and 0.41 (the Gulf of Maine, Clapham \& Mayo 1990)

The single instance of twins (in 1 of 37 females, or $2.7 \%$ ) is somewhat higher (but probably not significantly so) than the frequency with which multiple foetuses have been reported elsewhere $(0.39 \%$, Slijper 1962; 0.28\%, Chittleborough 1965).

The paucity of mother/calf pairs in the region (in both the catch and the observational data) is curious. Unlike in some other balaenopterids, strict segregation by reproductive condition is not known in humpback whales, although it has been suggested that during the winter females seek sheltered waters in which to give birth (Whitehead \& Moore 1982). Clapham \& Mayo (1987) presented data from the Gulf of Maine to suggest that female humpbacks preferentially visit certain areas in years when they have a calf. It is thus possible that many of the lactating females in the Arabian Sea population were concentrated elsewhere at the time of the whaling operations. Certainly the high pregnancy rate indicates that the population was healthy and reproducing well, although we of course have no data on calf mortality. A final possibility, that most calves had been weaned by November, seems unlikely in light of extensive data on weaning in other populations (Clapham \& Mayo 1990, Baraff \& Weinrich 1993).

\section{Pathology, length and external appearance}

Other evidence points to the discreteness of this population. The pathologies of the liver and vascular systems observed in the majority of examined whales from the Arabian Sea contrast with a lack of such abnormalities among whales caught south of latitude $35^{\circ} \mathrm{S}$ (despite the fact that the Soviet hemotologist Skryabin initiated specific studies of this nature during the 1963-64 and 1965-66 seasons). In addition, the Arabian Sea population, as sampled in the Soviet catches, was significantly different in coloration from that of Antarctic Area III, where humpbacks from the southern Indian Ocean feed (for an illustration of Antarctic whaling management areas, see Mackintosh 1942, Fig. 2, p 239). In the latter population, more than $80 \%$ of the whales are of type I, with predominantly black ventral coloration (Ivashin 1958), compared to only $46.2 \%$ from the Arabian Sea.

Antarctic humpbacks frequently have white oval scars on their bodies (Matthews 1937, author's unpubl. data). The lack of such scars among the Arabian Sea whales provides further support for the idea that this population does not originate in the Antarctic, and further that it does not migrate across equatorial latitudes. Yablokov (1966) explained the principle behind the use of variation in scarification of the skin in population studies, and the recording of such scars has been a standard part of biological examinations of whales taken commercially. White oval scars are believed to result primarily from attacks by cookie-cutter sharks (Isistius brasiliensis; Shevchenko 1970, 1977, Jones 1971). Lillie (1915), and later Mackintosh \& Wheeler (1929), considered these scars to be evidence of the regularity of whale migrations from warm to cold waters; this was based on the assumption that the scarring events occur in warm water, and that their quantity increases with the age (and subsequent migrations) of a given whale. Differences in scarring have been used to discriminate populations of sei whales 
Balaenoptera borealis (Omura 1950) and blue whales $B$. musculus and $B$. musculus brevicauda (Ichihara 1966).

Regrettably, numerous body measurements and age-distribution data from the Arabian Sea catches have not survived, making it impossible to compare the meristics and age structure of these humpbacks to those of other populations. However, we can compare the length data collected during the November 1966 catches. The mean length of the whales from the Arabian Sea $(13.1 \mathrm{~m})$ is greater than that of southern hemisphere humpbacks taken by the 'Sovetskaya Ukraina' later in the same season (December, $12.6 \mathrm{~m}$; January, $12.5 \mathrm{~m}$; February, $12.4 \mathrm{~m}$; and March, $12.1 \mathrm{~m}$ ). A more standardized comparison can be made by examining the lengths within a single class, pregnant females. In the Arabian Sea these averaged $13.6 \mathrm{~m}$, compared to $12.9 \mathrm{~m}$ for the Antarctic catch during the same whaling season. Furthermore, despite the fact that almost 53\% of the Arabian Sea catch were males, which are the smaller of the 2 sexes (Matthews 1937), the mean length of the Arabian Sea animals was greater than those taken in all other months. It was also greater than the value of $12.5 \mathrm{~m}$ reported for southern hemisphere pelagic humpback catches during an earlier period of exploitation between 1933 and 1945 (Tomilin 1967)

However, the absence of standard errors from the Antarctic sample makes inter-population comparisons difficult, and the data are reported with this caveat.

The apparently greater size of the Arabian Sea whales, the relatively high pregnancy rate among mature females, the low percentage of immature whales, and the even sex ratio all suggest a pristine population that had been previously untouched by whaling. The size difference relative to the Antarctic is all the more suggestive given that southern hemisphere humpbacks are normally somewhat larger on average than their boreal counterparts. The apparently healthy nature of this stock contrasts sharply with that of the Antarctic, which by this time had been nearly wiped out by intensive commercial whaling

In conclusion, several lines of evidence argue strongly for the discrete and boreal nature of the Arabian Sea humpback whale population. The extent of this population's range cannot be determined on the basis of present data, and we do not know whether the Arabian Sea animals undertake predictable seasonal movements within the northwestern Indian Ocean region. However, in November, their habitat appears to be defined by the coastal waters of the Arabian Peninsula to the west, the northwestern coast of the Indian Subcontinent to the east, and the Persian Gulf and Gulf of Oman to the north.

Ultimately, the question of this population's identity and migratory behavior will be answered with molecu- lar studies, which elsewhere have proved to be a valuable tool for assessing relationships and gene flow among and within populations of this species (Baker et al. 1993, Palsboll et al. 1995, Larsen et al. 1996). In particular, it will be interesting to see whether the Arabian Sea population has its origin in an ancient influx of whales from the southern hemisphere, a phenomenon which is evident in certain portions of the North Atlantic humpback population (Palsbell et al. 1995).

\section{Ecology}

The abundance of prey found in the stomachs of many of the whales reflects the productivity of the region. This is known to be unusually high for a tropical system, and derives from a combination of monsoon-related currents and strong upwellings between May and September (Smith 1968, Currie et al. 1973). As noted by Reeves et al. (1991), productivity off Oman is sufficient to support a sardine fishery as well as marine organisms normally characteristic of temperate latitudes. Consequently, it is not surprising that a humpback whale population could be supported in this habitat. The data indicate that the diet of the Arabian Sea humpbacks comprises a variety of prey items, including euphausiids and a variety of small schooling fish. This is typical of humpback whales elsewhere (Matthews 1937, Whitehead 1983, Payne et al. 1986, Perry et al. 1990).

The Arabian Sea humpback whale population's apparent year-round residence in the tropics represents a unique situation for this species, which in other oceans makes predictable seasonal migrations between high- and low-latitude waters. One question that should be addressed with further research is whether the behavior of the Arabian Sea animals differs from that of migratory conspecifics in other oceans. Elsewhere, the migration of balaenopterids appears to be a response to the need to exploit seasonal pulses of productivity in high latitudes while fasting in warm water during winter to conserve energy (Brodie 1975). In the humpback, this distinct geographical division of the year is paralleled by a strong seasonal segregation of behavior. whales feed and do not breed in summer, then mate and calve but do not eat in winter (Dawbin 1966). Thus, it is possible that removal of migratory constraints would have an impact on the social ecology of the species. This has apparently occurred with the so-called 'inshore' stock of Bryde's whales Balaenoptera edeni, which feeds year-round in the tropics and which (presumably as a result) is the only baleen whale that breeds throughout the year (Best 1977). The fact that the Arabian Sea humpback's breeding season appears to be tightly defined in winter suggests that 
these whales are similar to conspecifics in other oceans. The key factor may be the abundance of prey, which appears to be a seasonal phenomenon in the Arabian Sea

\section{Status}

The historic and present abundance of humpbacks in the Arabian Sea is unknown. That the whalers were able to locate and kill so many animals in a $10 \mathrm{~d}$ period suggests that the population was not small, although the tendency of humpbacks to aggregate might well have facilitated the capture of a significant portion of the population. Scientists on board the search vessel 'Bditelnyi-24' subjectively estimated that, during the November 1966 hunt, the animals that were killed represented approximately $60 \%$ of those sighted. Since it is very unlikely that the entire stock was observed during this short period, it is possible that, some $30 \mathrm{yr}$ later, the population is now substantial in size. However, despite an increase in both local interest and sighting reports off Oman in recent years (Papastavrou \& Salm 1991, Reeves et al. 1991), we currently know too little to assess the size and conservation status of this unique tropical stock of humpback whales, and further research is required.

Acknowledgements. I am very grateful to Bob Brownell and Phil Clapham for all of their help in the writing of this paper, and to Andy Dizon for help with graphics. I also thank Vladimir Mikhalev and Ted Sweeney for translation assistance, as well as Per Palsboll and 2 anonymous referees for their helpful comments.

\section{LITERATURE CITED}

Baker CS, Perry A, Bannister JL, Weinrich MT, Abernethy RB, Calambokidis J, Lien J, Lambertsen RH, Urbán Ramirez J, Vásquez $O$, Clapham PJ, Alling A, O'Brien SJ, Palumbi SR (1993) Abundant mitochondrial DNA variation and worldwide population structure in humpback whales. Proc Natl Acad Sci USA 90:8239-8243

Baker CS, Perry A, Herman LM (1987) Reproductive histories of female humpback whales Megaptera novaeangliae in the North Pacific. Mar Ecol Prog Ser 41:103-114

Baraff LS, Weinrich MT (1993) Separation of humpback whale mothers and calves on a feeding ground in early autumn. Mar Mammal Sci 7:49-54

Best PB (1977) Two allopatric forms of Bryde's whales off South Africa. Rep Int Whal Commn (Spec Iss 1):10-38

Brodie PF (1975) Cetacean energetics: an overview of intraspecific size variation. Ecology 56:152-161

Brown SG (1957) Whales observed in the Indian Ocean. Notes on their distribution. Mar Obs 27:157-165

Chittleborough RG (1953) Aerial observations on the humpback whale, Megaptera nodosa (Bonnaterre), with notes on other species. Aust J Mar Freshwat Res 4: $219-226$

Chittleborough RG (1958) The breeding cycle of the female humpback whale, Megaptera nodosa (Bonnaterre). Aust J Mar Freshwat Res 9:1-18

Chittleborough RG (1965) Dynamics of two populations of the humpback whale, Megaptera novaeangliae (Borowski). Aust J Mar Freshwat Res 16:33-128

Clapham PJ (1996) The soclal and reproductive biology of humpback whales: an ecological perspective. Mammal Rev 26:27-49

Clapham PJ, Leatherwood S, Szczepaniak I, Brownell RL Jr (1997) Catches of humpback and other whales from shore stations at Moss Landing and Trinidad, California, 1919-1926. Mar Mammal Sci 13 (in press)

Clapham PJ, Mayo CA (1987) Reproduction and recruitment of individually identified humpback whales, Megaptera novaeangliae, observed in Massachusetts Bay, 19791985. Can J Zool 65:2853-2863

Clapham PJ, Mayo CA (1990) Reproduction of humpback whales, Megaptera novaeangliae, observed in the Gulf of Maine. Rep Int Whal Commn (Spec Iss 12):171-175

Currie RI, Fisher AE, Hargreaves PM (1973) Arabian Sea upwelling. The biology of the Indian Ocean. Ecol Stud 3: $475-486$

Dawbin WH (1966) The seasonal migratory cycle of humpback whales. In: KS Norris (ed) Whales, dolphins and porpoises. University of California Press, Berkeley, p 145-170

Gervais P (1888) Sur une nouvelle espece de Megaptera (Megaptera indica) provenant du golfe Persique. Nouvelle archives du Museum d'Historre Naturelle, Paris, p 199-218

Ichnhara T (1966) The pygmy blue whale, Balaenoptera musculus brevicauda, a new subspecies from the Antarctic. In: Norris KS (ed) Whales, dolphins and porpoises. University of California Press, Berkeley, p 79-113

Ivashin MV (1958) The color type of the humpback whale body (Megaptera nodosa Bonneterre) of the southern part of the Indian Ocean. Informationnyj Sbornik VNIRO 2 $61-65$ (in Russian)

Jones EC (1971). Isistius brassliensis, a squaloid shark, the probable cause of crater wounds on fishes and cetaceans. Fish Bull US 69:791-798

Katona SK, Beard JA (1990) Population size, migrations and feeding aggregations of the humpback whale (Megaptera novaeangliae) in the western North Atlantic Ocean. Rep Int Whal Commn (Spec Iss 12):295-305

Larsen AH, Sigurjónsson J, Øien N, Vikingsson G, Palsbell PJ (1996) Population genetic analysis of mitochondrial and nuclear genetic loci in skin biopsies collected from central and northeastern North Atlantic humpback whales (Megaptera novaeangliae): population identity and migratory destinations. Proc R Soc Lond B 263:1611-1618

Laws RM (1959) The foetal growth rates of whales with special reference to the fin whale, Balaenoptera physalus, Linn. Discovery Rep 29:281-308

Lillie DG (1915) Cetacea. British Antarctic ('Terra Nova') expedition, 1910. Nat Hist Rep, Zool 1, No. 3:85-124

Mackintosh NA (1.942) The southern stocks of whalebone whales. Discovery Rep 22:197-300

Mackintosh NA, Wheeler JFG (1929) Southern blue and fin whales. Discovery Rep 1:257-540

Matthews LH (1937) The humpback whale, Megaptera nodosa. Discovery Rep 17:7-92

Mikhalev YA (1980) General regularities in prenatal growth in whales and some aspects of their reproductive biology. Rep Int Whal Commn 30:249-254

Nishiwaki M (1959) Humpback whales in Ryukyuan waters Sci Rep Whales Res Inst, Tokyo 14:49-87

Nishiwaki M (1966) Distribution and migration of the larger cetaceans in the North Pacific as shown by Japanese 
whaling results. In: Norris KS (ed) Whales, dolphins and porpoises. University of California Press, Berkeley, p $171-191$

Ohsumi SK, Nishiwaki M, Hibiya T (1958) Growth of fin whale in the northern Pacific. Sci Rep Whales Res Inst Tokyo 13:97-133

Omura H (1950) Whales in the adjacent waters of Japan. Sci Rep Whales Res Inst, Tokyo 4:27-113

Omura H (1953) Biological study on the humpback whales in the Antarctic whaling areas IV and V. Sci Rep Whales Res Inst, Tokyo 8:81-101

Palsboll PJ, Clapham PJ, Mattila DK, Larsen F, Sears R, Siegismund HR, Sigurjonsson J, Vasquez O. Arctander $P$ (1995) Distribution of mtDNA haplotypes in North Atlantic humpback whales: the influence of behaviour on populatıon structure. Mar Ecol Prog Ser 116:1-10

Papastavrou V, Salm RV (1991) A note on recent sightings and strandings of cetaceans in Oman: Ra's Sawadi to Rakhyut. UNEP Marine Mammal Tech Rep 3:211-217

Payne PM, Nicolas JR, O'Brien L, Powers KD (1986) Distribution of the humpback whale, Megaptera novaeangliae, on Georges Bank and in the Gulf of Maine in relation to densities of the sand eel, Ammodytes americanus. Fish Bull US 84:271-277

Payne RS, Guinee LN (1983) Humpback whale, Megaptera novaeangliae, songs as an indicator of 'stocks' In: Payne $\mathrm{R}$ (ed) Communication and behavior of whales. AAAS Selected Symposia Series 76:333-358

Perry A, Baker CS, Herman LM (1990) Population characteristics of individually ddentified humpback whales in the central and eastern North Pacifıc: a summary and critique. Rep Int Whal Commn (Spec Iss 12):307-317

Reeves RR, Leatherwood S, Papastavrou $V$ (1991) Possible stock affinities of humpback whales in the northern Indian Ocean. UNEP Mar Mammal Tech Rep 3:259-269

Shevchenko VI (1970) Puzzling white scars on a whale body Priroda 6:72-73 (in Russian)

Shevchenko VI (1977) Application of white scars to the study of the location and migrations of sei whale populations in Area III of the Antarctic. Rep Int Whal Commn (Spec Iss 1): $130-134$

This article was submitted to the editor
Slijper EJ (1962) Whales. Cornell University Press, New York Slijper EJ, van Utrecht WL, Naaktgeboren C (1964) Remarks on the distribution and migration of whales, based on observations from Netherlands ships. Bijdr Dierkd 34 $3-93$

Smith RL (1968) Upwellıng. Oceanogr Mar Biol Annu Rev 6: $11-46$

Tomilın AG (1967) Mammals of the USSR and adjacent countries, Vol IX, Cetacea. Izd Akad Nauk SSSR, Moskva. Israelı Program for Scientıfic Translations, Jerusalem

Townsend $\mathrm{CH}$ (1935) The distribution of certain whales as shown by logbook records of Amencan whaleships. Zoologica (NY) 19:1-50

Van Beneden PJ (1887) Histoire naturelle de la baleine à bosse (Megaptera boops). Mem Couronnés Acad R Belg 40:1-42

Whitehead H (1983) Structure and stability of humpback whale groups off Newfoundland. Can J Zool 61:1391-1397

Whitehead $H$ (1985) Humpback whale songs from the North Indian Ocean. Invest Cetacea 17:157-162

Whitehead H, Moore MJ (1982) Distribution and movements of West Indian humpback whales in winter. Can J Zool 60: 2203-2211

Wray P, Martin KR (1983) Historical whaling records from the western Indian Ocean. Rep int Whal Commn (Spec Iss 5): 218-242

Yablokov AV (1966) Changeability of mammals. Nauka Zhizn $1-363$ (in Russian)

Yablokov AV (1994) Validity of whaling data. Nature 367:108

Yablokov AV, Belkovich VM. Borisov VI (1972) Whales and dolphins. Academy of Sciences, Moscow (In Russian)

Yukhov VL (1969) Observations of cetaceans in the Gulf of Aden and the northwestern part of the Arabian Sea. In: Arsenev VA, Zenkovich BA, Chapskin KK (eds) Marine mammals. Akad Nauka, Moscow, p 327-328 (in Russian; English translation available from Natıonal Marine Mammal Laboratory, Seattle, WA)

Zemsky VA, Berzin AA, Mikhalev YA, Tormosov DD (1995) Soviet Antarctic pelagic whalıng after WWII: review of actual catch data. Rep Int Whal Commn 46: Annex E, A.ppendix 3

Mãnuscript first received: September 4, 1996

Revised version accepted: January 29,1997 